\title{
Assessing the Political Economy of Policy Instability and its Effect on Nigerian Economic Growth, 1970-2015
}

\author{
Gerald Chimezie Nwadike ${ }^{1}$, Kelechi Johnmary Ani $^{2,3}$ and Victor Ojakorotu ${ }^{4, *}$ \\ ${ }^{1}$ Department of Economics, Imo State University, Owerri, Nigeria \\ ${ }^{2}$ Department of History \& Strategic Studies, Alex Ekwueme Federal University Ndufu-Alike, Ikwo, Nigeria \\ ${ }^{3}$ Department of Politics \& International Relations, North West University, South Africa \\ ${ }^{4}$ Department of Politics and International Relations and Deputy Director, School of Government Studies, \\ North West University, South Africa
}

\begin{abstract}
This study examines the political economy of policy instability and its effect on the Nigerian economic growth from 1970 to 2015. The study tries to measure the effect of political policy instability on the Nigerian economic growth, focusing on the assessment of the relationship between political instability and unsustainable national economic growth in Nigeria. The researchers adopts the two stage least square of the static model and ADF and PP unit root test structural co-integration test as well as Pariwise Granger Causality. The research findings revealed that there is significant effect of policy instability on the Nigerian economic growth during the chosen period of observation and that there is no causality relationship between political instability and unsustainable national economic growth in Nigeria during the chosen period of study. In the light of the research findings, the researchers recommend transformational leadership and constitutional reform in Nigeria, which will go a long way to calm down the effect policy instability on Nigerian economic growth and development. Again the study calls for the promotion of citizenship over indignity in order to achieve cooperation and participation of all the masses and communities in the development process.
\end{abstract}

Keywords: Politics, Policy Instability, Economic Growth, Development and Nigeria.

\section{INTRODUCTION}

The pride of any government policy is the attainment of higher value level of development, which can drive national economy to that nation building level where the living standard of the citizenry can be measured by per capita Gross Domestic Product (GDP) growth that will not depreciate over time. It is then that the citizens would derive natural attachment to governance. Unfortunately, the attainment of this ultimate goal has been seriously threatened with instability in government policies amongst many nations of the globe. The policies of government are so powerful that on daily and weekly basis, it influences the national, regional and global market economies. Economic growth and political stability are deeply interconnected.

However, if the characteristics or even the identity of the successor of the incumbent government are not known with certainty, thus an increase of the propensity of a political change may lead to an increase in policy uncertainty. In fact, it implies an increase of the propensity of substituting a well known (even though, possibly, inefficient) government for a less known one.

*Address correspondence to this author at the Department of Politics and International Relations and Deputy Director, School of Government Studies, North West University, South Africa; Tel: 0183898859; Fax: 0865560368; E-mail: Victor.Ojakorotu@nwu.ac.za
On the one hand, the uncertainty associated with an unstable political environment can reduce investment and the speed of economic as well as national development. On the other hand, poor economic performance may lead to government collapse and political unrest. When government policies promote favourable political economy, there will be progressive economic growth that will lay the foundation for development. Development is critical and essential to the sustenance and growth of any nation. However, for a nation to be in a phase of development there must be some pre-requisites, which include socio-political and economic stability (Ogwumike, 1995).

The gap between the developed and the developing countries is not static or narrow but is continually widening due to the changing nature of economic governance in relation to socio-political and economic stability. A large majority of the world's population in developing countries live in a state of poverty. The problem of urban population, rural stagnation, unemployment and growing inequalities continue to face less developed countries, which Nigeria belongs. A country is classified as developed when it is able to provide qualitative life for her citizenry. Nigeria in the last fifty years has been battling with the problems of development in spite of huge human, material and natural resources in her possession. Hopes of accelerated development are difficult to realize since 
the factors that militate against national development with reference to political instability has not been identified. This gloomy situation is of great concern to stake holders and the concerned citizenry. Nigeria has not been able to engender meaningful national development in-spite of her huge resource endowment. This has greatly affected her quest to improve the quality of life of her citizens. Poverty, unemployment and starvation still pervade the nook and cranny of the country (Goodrich, 1992).

Unfortunately, the Nigerian State is a victim of highlevel policy and political instability, corruption, bad governance, and a cyclical legitimacy crisis with poor per capita GDP. Consequently, national underdevelopment could be accessed from the nature of her political environment (Mimiko, 1998). Nigeria has suffered changing policy dynamics from military authoritarian leadership to legitimacy crisis under democratic governance as well as political intrigues, in an ethnically - differentiated polity, where ethnic competition for resources drove much of the pervasive corruption, instability and profligacy (Omotoso, 2008). As the country continuously collapse into multiple nation building problems, the political gladiators constantly manipulate the people, policy and the political processes to advance their own selfish agenda. Thus, the Nigerian society has remained pauperized and the citizenry continuously wallow in abject poverty. This invariably led to increased criticism on the state as well as progressive violent uprising, attacks, militancy and terrorism as a negative expression of the people's anger against the ruling elite and the state of the economy as well as the political system. That naturally leads to low participation of the masses in government as many of the citizens perceive governance as been irrelevant to their lives. Patron client relationships grew to a prime role over the formal aspects of changing policies, politics, and corruption in the rule of law, poor-functioning political parties and the abortion of a credible electoral system. In order to break this cycle and ensure national development, good governance, accountability and transparency must be guaranteed (Adelman, 1995).

However, since policy and political stability are essential for national development, it's critical to ensure their sustenance in Nigeria. Meanwhile, since 1960, issues bordering on policy and political stability have been critical to the nation's unity and national integration; hence, effective strategies must be evolved to address this all important issue. This study, therefore examines political and policy instability as well as its effect on the Nigerian economic growth.

\section{CONCEPTUAL CLARIFICATION}

Policy instability is conceptualized as the propensity towards progressive change in governance polices due to change in the executive, either by constitutional or unconstitutional means. Over the years, the Nigerian political leadership has continuously changed a number of the policies made by their predecessors and often introduces new ones, which is aimed at attaining their own political goals that are mainly selfish and ethnocentric. One strong and fundamental argument underlying policy change is based upon the effects of political competition and uncertainty in regional productive economic decisions, such as investment, production or labor supply on economic and government policies. A high propensity of a change of government is associated with uncertainty about the new policies of the potential new government in Nigeria. If such new leader is risk-averse, he or she will take economic initiatives or may "exit" existing economic policy by promoting alternatives locally or engaging with foreign actors in the international political economy. Conversely, foreign investors prefer a stable political environment, with less policy uncertainty and less uncertainty about property rights and investments.

Scholars like Alesina and Tabellini (1990), Tabellini and Alesina (1990) as well as Cukierman, Edwards and Tabellini (1992) have outlined several case studies in which a government is uncertain about its survival and as a result engages in sub-optimal policies in order to "worsen" the state of the nation that they inherited by their successors. The case studies have in common, the idea that policy and political instability lead to economic inefficiencies. The most direct application of this idea for economic growth is in Alesina and Tabellini (1989), where they examined the effect of political uncertainty on investment and capital flight. The possibility of a government collapse leading to a new government that is prone to increased tax capital and productive activities implies a substitution of domestic productive investments in favor of consumption and capital flight and thereby leading to a reduction of domestic production.

A different argument leading to a similar relation between political instability and growth was suggested in Grossman (1991) analysis of revolutions. In countries where rulers are relatively weak and more easily overthrown, the probability of revolutions is 
higher and the citizens have higher incentives to engage in revolutionary activities rather than in productive market activities. A weak government is constantly under threat of losing office, thus may be particularly sensitive to the need of pleasing lobbyists and pressure groups, thus leading to a more direct effect of rent-seeking activities, which generates direct impact on policy decisions. On the contrary, a strong ruler who makes a revolution unlikely to succeed discourages revolutionary activities in favor of market activities. The study by Murphy, Shleifer and Vishny (1991) emphasize the negative effects of rent-seeking activities on economic growth.

A study of the effects of policy and political instability on economic growth needs to deal with multiple nation building problems, even if it is true that a high propensity of having frequent government changes reduces growth, it may also be the case that low growth increases the probability of government change. The effect of growth on government changes is likely to be observable in both democracies and in dictatorships. In democracies, a vast empirical literature has been established that high growth in preelection years increases the likelihood of re-election of the incumbent government. This is because voters do not re-elect incumbents if they perceive that the latter have mismanaged the economy. Specifically, voters appear to pay particular attention to income growth immediately before elections. In non-democracies with strong likelihood of coups d'etat, there may be decrease with both the level of GDP per capita and its rate of growth.

Low growth may increase popular dissatisfaction and create incentives for anti-government political action. That was the finding of Londregan and Poole (1990) in their studies on the economic determinants of unconstitutional transfers of power. A related issue is whether democratic institutions are harmful or conducive to economic growth. The popular argument in response is that democratic institutions may be harmful to growth but the basic idea underlying this view is that policy makers in democratic governments are subject to the pressures of interest groups, and thus follow opportunistic policies to enhance their chances of re-election instead of policies that enhance long term growth.

However, these arguments against democracy are not necessarily conclusive. First of all, dictators may also need to be opportunistic if their survival in office is threatened. Second, authoritarian regimes are not a homogenous lot, thus they include "technocratic" dictators and "kleptocratic" ones. While the apparent association of high economic growth with authoritarian regimes is suggested by the experience of several authoritarian "technocratic" regimes such as those at one time or another in Taiwan, Indonesia, Turkey and Chile; it is as well evident that for each "benevolent" dictator, one can observe at least as many "kleptocratic" and/or inept authoritarian regimes whose rule has led to systematic economic mismanagement and eventual political and economic collapse of their countries especially in Africa. One can therefore state that both on theoretical and empirical grounds, there is changing relationship between democracy and economic growth.

In fact, the empirical cross-country evidence on the relation between democracy and growth is quite mixed. Some early studies argue that democratic regime tend to slow economic growth while authoritarian regimes tend to stimulate it. However, others show that there is no systematic relation between long term growth and the democratic/ authoritarian nature of the political regime. Alesina and Rodrik (1991) present a model which is consistent with this inconclusive evidence. In their model, democracies should grow faster than "populists" or "kleptocratic governments. Based on the above statement, the researchers wish to examine policy instability effect on the Nigerian economic growth.

\section{RESEARCH HYPOTHESES}

$\mathrm{H}_{0}$ : There is no significant effect of policy and political instability on the Nigerian economic growth.

$\mathrm{H}_{1}$ : There is no causality relationship between policy instability and unsustainable national economic growth in Nigeria.

\section{NIGERIA, GOVERNANCE AND THE QUEST FOR POLICY STABILITY}

One of the major factors responsible for political instability is the failure of the political class to sufficiently adhere to the basic tenets of democracy and constitutionalism (Kew, 2006). As Harriman (2006:2) has rightly noted, this situation "has given rise to abuse of power, brazen corruption, disregard for due process and the rule of law, intolerance of political opposition, abuse of the electoral process and the weakening of institutions." This contradicts the tenet of governance, which presupposes the process of social 
engagement between the rulers and the ruled in a political community (Adejumobi, 2004). Good governance could be accomplished when the operation of government is in line with the prevailing legal and ethical principles of the political community. When this is the situation, systemic positive effect will be high, and the people would collectively aspire to participate in the activities of the state, knowing that adherence to the rules and procedures would serve the interest of the greatest number of the population. Deprivation of benefits and selective justice would not be encouraged, as individuals' rights would be protected within the ambit of the law. Political leaders should hold tenaciously to the watchwords: transparency, sustainability and accountability in governance.

Successive governments in Nigeria have indicated their awareness of this as a way of ensuring stability and legitimacy. The Jaji Declaration of the Murtala/Obasanjo administration, Ethical Re-orientation Campaign of Shagari's Second Republic, War Against Indiscipline (WAI) of the Buhari/ldiagbon regime, Babangida's Committee on Corruption and other Economic Crimes, the numerous probe panels of the Abacha years and the current War Against Corruption (Diamond, 1991; Bello-Imam, 2004), are a façade of genuine measures to promote good governance through the eradication of corrupt practices. Between 2000 and 2003, two anti-corruption agencies were established to complement Obasanjo's administration's crusade (Kew, 2006). However, "the overall system remains deeply compromised. Federal government contracts are routinely inflated to provide kickbacks for officeholders, and contractors frequently provide substandard or nonexistent services. State and local level of corruption has been far more brazen (Kew, 2006)".

The rules of good governance are not observed by the Nigerian leaders except in its application to frustrate the opposition (Kew, 2006; Adeyemo, 2006). The deeper motives of introducing these measures were rarely nationalistic. Omotoso (2008) notes that the 1999 constitution is directly or indirectly promoting indignity in the country, as found in section 318(1) of paragraph (IV).

However, Nigerians are primarily motivated by selfinterest for the acquisition of wealth and power. And the scourge of bad governance persists thereby isolating the political elite from the generality of the citizenry. Sklar et al. (2006) sum it up when they stated that the growing distance between the political elite and the general public, however has undermined accountability, promoted poverty and frustration, leading to the slow pace of change and increased public anger. The fallout of the hypocritical postures towards corrupt practices has been a ceaseless cycle of political, policy and legitimacy crises. Citizens express their discontentment against irresponsible governance and are increasingly losing their faith as well as withdrawing their legitimacy to the Nigerian political system.

This situation gained wider currency in the Niger Delta region, where oil exploration had further impoverished the people. The region produced the bulk of the wealth of Nigeria, yet the communities are highly undeveloped and polluted. Since 1965 when oil was discovered in Oloibiri, the Niger Delta Basin has produced 30billion barrels of crude oil and about 30 trillion cubic feet of gas. Deep-water exploration commenced in the early 1990s and currently its reserves account for 39 percent of world deep-water reserves (Harriman, 2006). Environmental degradation and lack of basic needs like good roads, potable water was the lot of the people. Notwithstanding the establishment of government agencies and changing policies like the 1965 Niger Delta Basin Development Board (NDBDB), Oil Minerals Producing Areas Development Commission (OMPADEC), in 1992, and the current Niger Delta Development Commission (NDDC), there has been little to show in terms of physical infrastructural development in the area to justify the quantum of wealth the region produced to the coffers of the federal government. Eventually, problems of legitimacy, transparency, policy changes and mismanagement tainted by political jobbery have crippled these agencies that were established to deliver development in the region. This is aggravated by faulty institutional framework and poor technical and managerial capacity for effective programme delivery (Harriman, 2006).

Nigeria's oil revenue by 1980 stood at 25 billion US dollars (Mayer et al., 1996). Though there was a decline in the late 1980s, the initial proceeds from the oil boom were expended on projects with no positive impact on the economy (Mayer et al., 1996; Joseph et al., 1996). This triggered off debt and corruption. By 1989, Nigeria's external debt stood at 30 billion US dollars. By 1994, it rose to 36 billion US dollars, including the repayment arrears that were due at the end of the year. The oil boom in reality was nothing but a vehicle that could not lead to development destination. It was a source of income and yet a 
"source of dependence". Robinson (2004) noted that the Nigerian government exported 20 billion (US dollars) worth of oil in 2003 but its people still scrape by on an average wage of just a dollar per day-oil money has often been wasted in kickbacks and bribes. The country's economy has struggled with years of mismanagement.

The impoverishment of the Niger Delta area had begun since the first republic. Adaka Boro's struggle was a response to the situation (Darah, 1995). The extreme deprivation peaked during the years that followed the emergence of the Movement for the Survival of the Ogoni People (MOSOP), in the Abacha years, and intensified with the "judicial murder" of Ken Saro-Wiwa and eight other Ogoni activists by Sani Abacha. The people demanded an equitable share of the proceeds of oil revenues to improve their living and environmental conditions. Notwithstanding the changing developmental policies in the Niger Delta, the area is still characterized by poor road networks, lack of water, electricity, schools and hospitals. The numerous Niger Delta groups have continuously asked for improved economic development or the area, considering the fact that the oil resources in their area are the pillar of Nigerian national economy. The demands of the oil producing communities were often met with repressive force. A select few, mostly the political elites, were given a foretaste of the booty through the game of political intrigues of divide and rule tactics. The more the government and oil multinational companies use repressive force, the more the instability in the polity and the more the people distance themselves from political participation. The cycle of crises and chaos, which has engulfed the Niger Delta region today, with its multiplier effects on the national politics, began as a result of deprivation as well as bad governance, and that has been worsened by the fact that the changing agencies meant to develop the Delta region were merely political policies for increase resource exploitation and patronage to the members of the political elite.

For instance, it was discovered that Nigerian leaders have looted over US $\$ 500$ billion since independence (Epia, 2006). Nigeria's former president, Olusegun Obasanjo confirmed that the country's indebtedness to the London Club as at November 2006 was N270 billion (Daniel, 2006), so, the amount of misappropriated funds is more than the totality of Nigeria's indebtedness. The London Club debt portfolio currently comprises Par Bonds and Promissory Notes. The residual principal outstanding on these instruments amounts to US $\$ 1,441,793,302$ and US $\$ 544,528,914$ respectively. In addition to these liabilities, the Par Bonds have associated oil warrants that require payments to be made when oil prices rise above per barrel consistently for six months. The Par Bonds have their origin in the arrears of term loans owed to foreign commercial banks as well as some arrears of letters of credit, bills of collection, open accounts, etc which were accumulated by Nigeria in the 1980s. These Bonds are expected to be fully paid off on November 15, 2020 (Daniel, 2006). According to another analyst, with $75 \%$ of the citizens living on less than US\$I per day while about US\$ 300 billion oil wealth has disappeared from the country, Nigeria presents a classical example of how people in a resources rich country could wallow in abject poverty (Adeniyi, 2006).

However, this situation, as Ake (1995) has indicated, was the product of the pattern of state of affairs in the developing world. According to Ake (1995), the high premium on political power, and the attendant intense struggle for it, marginalized national development for the promotion of the personal interests of the political leaders. Besieged by a multitude of hostility forces, most of the leaders in Africa are politically insecure. They are so completely engrossed in the struggle for survival that they are hardly able to address the problem of development (Ake, 1995).Thus; they continue to change policies in their bid to enthrone a policy that would secure their continuous grip on political power.

It is instructive to note that the leadership problem in the Nigerian polity was a manifestation of the dysfunctional pattern of the years of military interregnum as well as abortion of democratic policies in the years ahead of them (Omo- Bare, 1996; KirkGreene \& Rimmer, 1981; Mundt \& Aborisade, 2005; Mayer et al., 1996; Joseph et al., 1996). The leadership pattern in Nigeria lacks the necessary focus capable of instilling national development and promotes political stability (Sklar et al., 2006). Rather, Nigerian leaders are preoccupied with their desires for the appropriation and privatization of the Nigerian state (Sklar et al., 2006; Ake, 1995). The fall of the Second Republic, for instance, was precipitated by the pervasive corruption and the attendant political violence that greeted electoral manipulations, in a bid to stick to power (Ayeni, 1988). Similarly, the military coups and countercoups were also plagued by bad leadership, although their successors as well as policy decrees that followed one military administration to another did not fair better. Consequently, development performance was slowed 
down, and policy as well as political instability continued to pervade the polity, as focus was shifted to combat the looming forces of insecurity and internal regime instability.

\section{NATIONAL DEVELOPMENT PLAN AND POLICY CHANGES IN NIGERIA}

We have had series of development plans in Nigeria. Nigeria is permanently hunted by the spectra of development. Its forty-nine years of independence actually are rolling by daily in search of development. The myth of growth and development is so entrenched that the country's history passes for the history of development strategies and growth models from colonial times up to date. Nigeria has tried or experimented different models of development (Aremu, 2003).

Two years after independence, the first National Development Plan policy was formulated between 1962 and 1968 with the objectives of developing opportunities in health, education and employment as well as improving access to these opportunities, etc. This plan failed because fifty percent of resources needed to finance the plan was to come from external sources and only fourteen percent of the external finance was received (Ogwumike, 1995).

The collapse of the First Republic and the commencement of the Nigerian Civil War also disrupted the above plan. After the civil war in 1970, the second national development plan of 1970 to 1974 was launched. The development policy priorities were in agriculture, industry, transport, manpower, defence, electricity, communication, water supply and provision of social services. The third development plan, covering the period of 1975 to 1980 was considered more ambitious than the second plan. Emphasis was placed on rural development and efforts to revamp agricultural sector. The fourth plan of 1981 to 1985 recognized the role of social services, health services, etc. The plan was aimed at bringing about improvement in the living conditions of the people. The specific objectives were an increase in the real income of the average citizen, more even distribution of income among individuals and socio-economic groups, increased dependence on the country's material and human resources, a reduction in the level of unemployment and underemployment (Ogwumike, 1995).

During these periods, Nigeria's enormous oil wealth was not invested to build a viable industrial base for the country and for launching an agrarian revolution to liquidate mass poverty. For instance, the Green Revolution Programme that replaced Operation Feed the Nation policy failed to generate enough food for the masses. In the recent past, various strategies or policies for development have also been tried with little or no sustainable result; among these were the structural adjustment programme (SAP), Vision 2010, National Economic Empowerment and Development Strategy (NEEDS), creation of development centers, etc. Currently, the seven-point agenda of the present administration with vision 2020 without any clear methodological approach towards achieving them has gradually collapsed in the midst of worsening economy. It is obvious that the current results so far are not what development connotes.

\section{EMPIRICAL LITERATURE REVIEW}

Some researchers in Nigeria have studied the relationship between national development and political instability. Adam and Sanni (2005) cited in Kolapo and Adaramola (2012) examined the roles of political instability on Nigeria's economic and national development using Annover and ancover regression analysis. The authors discovered a one-way causality between Nigeria's economic development and political instability and a two-way causality between policy instability, consistence and high increase of corruption in public office. They also observed a positive and significant relationship between poor national development and duplication of project as well as lack of implementation of the approved national development planning in Nigeria. The authors advised that government should encourage the development of political institutions since it has a positive effect on economic growth and national development. Chinwuba and Amos (2011) also maintain that political instability is a key to national development and economic growth using mean, standard deviations and chi-square approach for the analysis of their studies. Afees and Kazeem (2010) empirically examined the causal linkage between inconsistencies in Nigerian government regimes, and national development and economic growth in Nigeria from 1970 to 2004. The result showed that political stability and underdevelopment drive national development and economic growth in Nigeria using questioner's method.

Pedro and Erwan (2004) assert that political inconsistence/political instability leads to poor national development of a nation. Abdullahi (2005) also agrees with the assertion that political instability, and under- 
development in Nigeria is an engine to her poor national economic growth. Moreover, Agarwal (2001) argues that financial sector development facilitates economic development and capital market development, and in turn raises real growth of the economy but not until the political state of such country seem to be stable. In the same vein, Kolapo and Adaramola (2012) found that Nigerian capital market development has significant relationship with national development. Obamiro (2005) cited in Kolapo and Adaramola (2012) investigated the role of the Nigeria political stability and stock market in the light of national economic development. The authors reported that there is a significant positive effect of both Nigeria political stability and stock market on economic development growth. The study suggests that government should create more enabling environment so as to increase the stability and efficiency of her political policies and stock market to attain higher national economic development/growth. Osinubi and Amaghionyeodiwe (2003) also examined the relationship between Nigeria stock market policy consistence and national development during the period 1980-2000 using ordinary least squares regression (OLS). The result showed that there is a positive relationship between the stock market policy development and national development, thereby suggesting the pursuit of policies geared towards rapid development of the stock market.

\section{METHODOLOGY}

This section describes the procedures employed for the study. First, we give a brief discussion of single equation estimation, where cross section growth regressions are considered. The primary purpose of employing this method is to facilitate a comparison of our results with those of other cross section studies in the recent literature such as those of Barro (1990\& 1991). A major drawback of a single equation approach for our study is that it does not take into account the joint endogeneity of the growth and government change. Hence, later the study turns to a discussion of a simultaneous equation methodology, which constitutes the primary focus of this study.

Political and policy instability defined as the propensity of an imminent government and policy change, is not directly observable. Since "government change" is a discrete phenomenon, we employ limited dependent variable estimation methods. Propensity of government and policy change is characterized as a function of economic and political variables. We estimate the probit specification described below using time-series data (for notational convenience, time and country indicators are omitted):

where:

$C^{*}=\beta X_{1}+\eta$

$\mathrm{C}^{*}=$ a latent (dummy) variable such that when $\mathrm{C}^{*}>0$ we observe the occurrence of a government change, and we do not observe government change otherwise. $\mathrm{x}_{1}=$ (economic and political) variables that determine the occurrence of government change.

$\eta=$ normally distributed error term with mean zero.

This specification facilitates an estimation of probabilities of government change that varies over time and across countries. We then average these annual measures of probability for Nigeria over time so as to obtain a linear time series data which measure for instability, which we call INS, regressions described next.

\section{Economic Growth}

A cross section estimation of growth is described with the following specification:

$Y=\lambda X_{2}+\theta(I N S)+E$

where:

$\mathrm{Y}=$ average economic growth in the country for the sample period.

$\mathrm{x},=$ economic variables that explain economic growth which include government expenditure, revue, and money supply.

INS = measure of political instability, obtained from equation

$\varepsilon=$ error term with mean zero.

This approach has two problems. First, as instability is a generated regressor, the standard errors of the second stage equation are generally inconsistent. A more serious problem is that of simultaneity. Since the propensity of government change and economic performance are endogenous, equations (1) and (2) are both likely to be biased. We address this issue by using a simultaneous estimation of the two equations for growth and political instability as described next, 


\section{A Simultaneous Equations Approach}

Let us define the following structural equation system, where the dependent variables of government change and growth are as before (but now both with yearly frequency):

$c^{*}=\alpha_{c} X_{C}+\beta_{c c} X+Y_{C} Y+\mu_{1}$

$Y=\alpha_{\mathrm{y}} X_{\mathrm{y}}+\beta_{\mathrm{y}} \mathrm{x}+\mathrm{Y}_{\mathrm{y}} \mathrm{c}^{*}+\mathrm{u}_{2}$

where:

$\mathrm{Y}=$ annual rate of economic growth,

$\mathrm{X}=$ exogenous variables that determine both government change and growth,

$\mathrm{x},=$ exogenous variables (economic and political) that determine the occurrence of government change only (i.e instruments for instability), $x y=$ exogenous variables that determine economic growth only (i.e. government expenditure, revenue, and money supply instruments for growth),

$\varepsilon=$ error terms are assumed to be bivariate normally distributed with zero mean and variance covariance matrix.

The estimation proceeds in two stages: estimation of reduced forms of both equations, and then extraction of the structural parameters from the reduced forms. The likelihood function of the system factors out into the product of the likelihood function corresponding to the growth equation and the likelihood function of the $p$ \& that corresponds to the government change equation.

The coefficients $Y_{c}$ and $Y_{y}$ take into account the contemporaneous feedback between growth and changes of government, while the $\beta$ coefficients measure the effects of the exogenous variables. One way of identifying the system requires that at least one of the $X_{c}$ and $X_{y}$ variables exist; that is, we need one exogenous variable in the growth equation which is not in the equation for government change, and vice-versa. An alternative way of identifying the system of equations is to impose restrictions on the contemporaneous feedback, i.e. $Y_{C}=0$ or $y_{y}=0$. In order to test the model (a chi-square test); there must at least be one over identifying restriction, in addition to the restrictions needed to identify the model fully. We discuss the economic and political variables used as our identifying restrictions.
This model, a simultaneous equation system involving a latent variable, is described in Heckman (1978). While this system could in principle be estimated by standard maximum likelihood methods, the resulting likelihood function is extremely non-linear and thus difficult to maximize using standard methods. Londregan and Poole (1990) use the results of Newey (1987) to estimate this type of system through an application of Amemiya's Generalized Least Squares Technique (AGLS). The study employs the same econometric methodology.

This greatly simplifies estimation of the reduced form, since the equations can be estimated sequentially. The growth equation is estimated as a function of all the exogenous variables in the system using OLS. The residuals from this regression are then added as a regressor, in addition to all the exogenous variables in the system, for the reduced form of the probit estimation for government change. After adjusting to take into account correlation across the equations, the resulting coefficients are the maximum likelihood estimators of the reduced form parameters. The reduced forms take into account that there may be shocks common to both growth and policy instability.

\section{RESULTS}

\section{Unit Root Test Results}

The augmented Dickey-fuller (ADF) and Philip Perron (PP) unit root test with constant and trend level were employed in this study in order to eliminate the spurious content in those variables. Thus, below are the figure and value of ADF and PP-statistic at 5 percent critical value.

The Table 1 was used to test the stationary state of the above variables. Stationary, means to remove or adjust the trend in the time series in econometrics (lyoha, 2004; GuiJarity, 2005). Any model in a given study that did not test or adjust the trend (i.e. stationary) in the variables, the result of such model is called non-sensical or superiors result if used for prediction or forecasting, hence will be miss leading.

The above unit root test shows that these variables; Gross Domestic Product (GDP), Government Expenditure (GXE), Government Total Revenue (GTR) Political Instability (INS) and Broad Money Supply (BM2) are stationary (i.e. they are free from unit root syndrome), at $1^{\text {st }}$ difference, with the application of both $A D F$ and PP respectively. Thus, since their ADF and 
Table 1: (ADF) and Philip Perron (PP) unit root test

\begin{tabular}{|c|c|c|c|}
\hline \multicolumn{4}{|c|}{$\begin{array}{l}\text { Null Hypothesis: Unit root (individual unit root process) } \\
\text { Series: GEX, GTR, INS, GDP, BM2 } \\
\text { Date: 12/29/16 Time: 10:54 } \\
\text { Sample: } 19702015 \\
\text { Exogenous variables: Individual effects, individual linear }\end{array}$} \\
\hline Method & & Statistic & Prob.** \\
\hline PP - Fisher Chi-square & & 363.617 & 0.0000 \\
\hline PP - Choi Z-stat & & -12.9786 & 0.0000 \\
\hline \multicolumn{4}{|c|}{$\begin{array}{l}\text { ** Probabilities for Fisher tests are computed using an asymptotic Chi-square distribution. All other tests assume asymptotic normality. } \\
\text { Intermediate Phillips-Perron test results D(UNTITLED) }\end{array}$} \\
\hline Series & Prob. & Bandwidth & Obs \\
\hline $\mathrm{D}(\mathrm{GEX})$ & 0.0000 & 2.0 & 44 \\
\hline $\mathrm{D}(\mathrm{GTR})$ & 0.0005 & 3.0 & 44 \\
\hline D(INS) & 0.0000 & 0.0 & 44 \\
\hline $\mathrm{D}(\mathrm{GDP})$ & 0.0000 & 4.0 & 44 \\
\hline $\mathrm{D}(\mathrm{BM} 2)$ & 0.0000 & 8.0 & 44 \\
\hline \multicolumn{4}{|c|}{$\begin{array}{l}\text { Null Hypothesis: Unit root (individual unit root process) } \\
\text { Series: GEX, GTR, INS, GDP, BM2 } \\
\text { Date: 12/29/16 Time: 10:54 } \\
\text { Sample: } 19702015 \\
\text { Exogenous variables: Individual effects, individual linear }\end{array}$} \\
\hline Method & & Statistic & Prob.** \\
\hline $\begin{array}{l}\text { PP - Fisher Chi-square } \\
\text { PP - Choi Z-stat } \\
{ }^{* *} \text { Probabilities for Fishe } \\
\text { Intermediate Phillips-Per }\end{array}$ & d using a & $\begin{array}{l}854.248 \\
-26.0981 \\
\text { distribution. }\end{array}$ & $\begin{array}{l}0.0000 \\
0.0000 \\
\text { ne asymptotic normality }\end{array}$ \\
\hline Series & Prob. & Bandwidth & Obs \\
\hline $\mathrm{D}(\mathrm{GEX}, 2)$ & 0.0000 & 3.0 & 43 \\
\hline $\mathrm{D}(\mathrm{GTR}, 2)$ & 0.0000 & 0.0 & 43 \\
\hline $\mathrm{D}(\mathrm{INS}, 2)$ & 0.0000 & 7.0 & 43 \\
\hline $\mathrm{D}(\mathrm{GDP}, 2)$ & 0.0000 & 42.0 & 43 \\
\hline $\mathrm{D}(\mathrm{BM} 2,2)$ & 0.0000 & 42.0 & 43 \\
\hline
\end{tabular}

PP statistical value $(-26.0981,-12.9786)$ respectively, as well as the Probability values that stood at zero value. In fact, all the variables were stationary at first difference. In other words, these variables were statistically significant in absolute terms at $5 \%$ levels of significance. Thus, it means that the Gross Domestic product (GDP), Government Expenditure (GXE), Government Total Revenue (GTR) Political Instability (INS) and Broad Money supply (BM2) that exhibited unit root at levels test of ADF and PP has been removed after the $A D F$ and $P P$ test at the first difference.
The implication is that these variables were stationary at first difference. However, it was found that both the ADF and PP results with trend and intercept indicated that the time series are integrated of order 1 (I) for all the variables. Thus, the linear combination of series integrated of the same order is said to be cointegrated. In other words, the variables tested, were all stationary at first difference order or at integration of order one (i.e. I (I). The study then conclude that the difference in trend and intercept (unit root in these time series (variables) used has been removed. In order wards, the study rejects the null hypothesis and accept that the variables were all stationary at order one. 
Again, been stationary, implies that these variables are co-integrated since they all have the same order of integration. This instigated the researchers to carry out the co-integration test and other estimations models, in order to analyze the nature of short and long-run relationship among the variable for each of the models.

\section{Co-integration Test}

\begin{tabular}{|c|c|c|c|c|}
\hline \multicolumn{5}{|c|}{ Unrestricted Co-integration Rank Test (Trace) } \\
\hline \multicolumn{2}{|l|}{ Hypothesized } & \multirow{2}{*}{$\begin{array}{l}\text { Trace } \\
\text { Statistic }\end{array}$} & \multicolumn{2}{|l|}{0.05} \\
\hline No. of $\mathrm{CE}(\mathrm{s})$ & Eigenvalue & & \multicolumn{2}{|c|}{ Critical Value Prob.** } \\
\hline None * & 0.999979 & 641.7295 & 69.81889 & 0.0001 \\
\hline At most 1 * & 0.950699 & 168.5681 & 47.85613 & 0.0000 \\
\hline At most 2 * & 0.340872 & 36.13640 & 29.79707 & 0.0081 \\
\hline At most 3 * & 0.220868 & 17.79554 & 15.49471 & 0.0221 \\
\hline At most 4 * & 0.143473 & 6.814265 & 3.841466 & 0.0090 \\
\hline \multicolumn{5}{|c|}{$\begin{array}{l}\text { Trace test indicates } 5 \text { co-integrating eqn(s) at the } 0.05 \text { level } \\
\star * \text { denotes rejection of the hypothesis at the } 0.05 \text { level } \\
\star * \text { MacKinnon-Haug-Michelis (1999) p-values }\end{array}$} \\
\hline
\end{tabular}

Under the Johansen Co-integration Test, there are two co-integrated vectors. In Johansen's Method, the eigen-value statistic is used to determine whether cointegrated variables exist. As can be seen from the eigen-value statistics values, here only the absolute values of variable Gross Domestic product (GDP), Government Expenditure (GXE), Government Total Revenue (GTR) Political Instability (INS) and Broad Money supply (BM2) were found to be different from zero values while the Max-Eigen statistic values were all greater than the $5 \%$ level of critical value (i.e. 641.7295GDP > 69.81889, 168.5681GEX $>47.85613,36.13640 \mathrm{GTR}>29.79707,17.79554$ INS > 15.49471 and 6.814265BM2 > 3.841466). We therefore conclude that there exists a five long-run relationship co-integration among three variables. In other words, the null hypothesis of no co-integration among the variables is rejected since five among the variables in the five equations at $5 \%$ was statistically significant. The test result shows the existence of a long-run equilibrium relationship among the variables.

\section{Two-Stage Least Squares}

The dynamic equation in Two-Stage Least Squares Regression shows a strong and negative significant relationship between Political Instability (INS), Government Total Revenue (GTR) and Broad Money supply (BM2) instruments for instability and Gross

\begin{tabular}{|c|c|c|c|c|}
\hline \multicolumn{5}{|c|}{$\begin{array}{l}\text { Dependent Variable: GDP } \\
\text { Method: Two-Stage Least Squares } \\
\text { Date: 12/29/16 Time: 11:36 } \\
\text { Sample (adjusted): } 19712015 \\
\text { Included observations: } 45 \text { after adjustments } \\
\text { Instrument specification: LOG(GDP) C INS LOG(GEX) LOG(GTR) } \\
\text { LOG(BM2) }\end{array}$} \\
\hline Variable & Coefficient & Std. Error & t-Statistic & Prob. \\
\hline C & 155020.0 & 1230549. & 0.125976 & 0.9004 \\
\hline $\mathrm{D}(\mathrm{INS})$ & -6294123 & 5086454 & -1.237428 & 0.2231 \\
\hline GEX & 101.1208 & 19.29872 & 5.239765 & 0.0000 \\
\hline GTR & -31.76129 & 19.37855 & -1.638993 & 0.1091 \\
\hline BM2 & -0.003832 & 0.256244 & -0.014953 & 0.9881 \\
\hline R-squared & 0.826064 & Mean dep & dent var & 4100928. \\
\hline Adjusted R-squared & 0.808670 & S.D. depe & dent var & 15619667 \\
\hline S.E. of regression & 6832244. & Sum squa & d resid & $1.87 E+15$ \\
\hline F-statistic & 32.51859 & Durbin-Wa & son stat & 2.363063 \\
\hline Prob(F-statistic) & 0.000000 & Second-St & ge SSR & $4.66 \mathrm{E}+15$ \\
\hline J-statistic & 1.611164 & Instrumen & rank & 6 \\
\hline Prob(J-statistic) & 0.204328 & & & \\
\hline
\end{tabular}

Domestic Product (GDP) exogenous variables (economic and political) that determine the occurrence of government change only. A shilling increase in instruments for instability (INS) will lead to (-62.94123, 31.76129 and-0.003832) or about 62,31 and 1 cents decrease in Gross Domestic Product (GDP) respectively, which indicate poor performance level of the economy with the presence of policy instability. This supports the evidence from Goodrich (1992) on political Instability and U.S economy. The coefficient of Government Expenditure (GXE) has positive relationship with gross domestic product (the dependent variable). The implication is that an increase in GEX as one of exogenous variables that determine economic growth only will lead to increase in the gross domestic product (GDP) by 101.1208 percent.

However, the coefficients of determination $\mathrm{R}^{2}$ for the Two-Stage Least Squares Regression models stood at $.82 \%$ which signifies that there is $82 \%$ degree of the influence of the exogenous variables (economic and political) that determine the occurrence of government change (affecting Gross Domestic Product (GDP), Government Expenditure (GXE), Government Total Revenue (GTR) Political Instability (INS) and Broad money supply (BM2). The positive sign of the correlation coefficient also signifies that $82 \%$ of total variation in GDP could be attributed to the specified 
explanatory variables while $18 \%$ is attributed to the error terms.

Meanwhile, the $\mathrm{f}$ - ratio, which is the joint test of significance of all parameter estimated in the models, are statistically significance at 5 percent level. The calculated values of $\mathrm{f}$ - ratio are 32.51 , greater than the Tabulated or $\mathrm{f}$ - critical value at 3.01 . The Durbin Watson test result is 2.363063 , showing no presence positive of Auto-Correlation.

\section{The Granger Causality Test}

In attempt to investigate the effect of policy instability on the Nigerian economic growth led the researchers to test for the causality relationship among the variables.

\begin{tabular}{|lllll|}
\hline Pairwise Granger Causality Tests & & & \\
Date: $12 / 29 / 16$ Time: $23: 15$ & & & \\
Sample: 19702015 & & & \\
Lags: 2 & & & & \\
\hline Null Hypothesis: & Obs & F-Statistic Prob. \\
\hline GEX does not Granger Cause GDP & 44 & 37.6845 & $8 . E-10$ \\
GDP does not Granger Cause GEX & & 25.1136 & $1 . \mathrm{E}-07$ \\
\hline GTR does not Granger Cause GDP & 44 & 2.20369 & 0.1240 \\
GDP does not Granger Cause GTR & & 0.52647 & 0.5948 \\
\hline INS does not Granger Cause GDP & 44 & 34.2654 & $3 . E-09$ \\
GDP does not Granger Cause INS & & 4669.03 & $4 . E-47$ \\
\hline BM2 does not Granger Cause GDP & 44 & 0.62899 & 0.5384 \\
GDP does not Granger Cause BM2 & & 0.20364 & 0.8166 \\
\hline
\end{tabular}

Form the results we compare the computed $\mathrm{F}^{\mathrm{x}}$ value or Pro- value with reference to the critical $f$-ratio at 5 percent level of significance for final decision. These results reveal that Gross Domestic Product, Government Expenditure (GXE), Government Total Revenue (GTR) Political Instability (INS) and Broad Money supply (BM2) does not granger thereby cause each other since their estimated Pro- value coefficient shows higher probability (i.e. 8.9998 1.E.07, 0.1240, $0.5948,0.04366,3 . E 0.9$ and 08166 ) respectively. In other words, the past value of the Gross Domestic Product, Government Expenditure (GXE), Government Total Revenue (GTR) Political Instability (INS) and Broad money supply (BM2) does not both theoretical and statistically, in many ways granger cause the present value of each other in Nigeria economy within the period of study. This could be linked to effect of political instability in the Nigerian economy, which has halted the macroeconomic variable not to react or response to present value impact on the presence value. The implication is that the effect of political instability in the Nigerian economy really surfaced in the inability of macroeconomic variable to respond to each other.

\section{Evaluation of Working Hypothesis}

\section{Hypotheses I}

$\mathrm{H}_{\mathrm{o}}$ : There is no significant effect of political policy instability on the Nigerian economic growth.

In this section we look at how changes (increase and decrease level) of the exogenous factors [i.e. Gross Domestic product (GDP) with respect to the individual explanatory variables. From the Two-Stage Least Squares Regression, it was observed that Government Expenditure (GXE), Government Total Revenue (GTR) Political instability (INS) were statistically significantly with their t-statistical value $(1.237428,5.239765$ and 1.638993$)$ as it was greater than the $5 \%$-critical value of (1.201) percent and indeed passed the individual test of significance at $5 \%$ significance with their right sign in the both models respectively. The study therefore rejected the null hypothesis one and accepted the alternative hypothesis. In other words, there is significant effect of political policy instability on the Nigerian economic growth during the chosen period of observation.

\section{Hypotheses II}

$\mathrm{H}_{0}$ : There is no causality relationship between political instability and unsustainable national economic growth in Nigeria.

Again, the study tests this hypothesis with Granger Causality Tests figures. The results revile that Gross Domestic Product, Government Expenditure (GXE), Government Total Revenue (GTR) Political Instability (INS) and Broad money supply (BM2) does not granger cause each other. In other words, the past value of the Gross Domestic Product, Government Expenditure (GXE), Government Total Revenue (GTR) Political instability (INS) and Broad money supply (BM2) does not both theoretical and statistically, in many ways granger cause the present value of each other in Nigeria economy within the period of study. Therefore, the study accepts the null and rejects the alternative hypothesis three of this paper that says that there is no causality relationship between political instability and unsustainable national economic growth in Nigeria. 


\section{CONCLUSION}

This paper has carefully discussed the effect of political and policy instability on the Nigerian economic growth. It examined the problems of national economic growth and development and change in government over the period of 45 years in Nigeria, and it carefully outlined the driving forces of economic growth and development in some of the Asia countries as models that Nigeria should adopt for economic growth and development. The paper also suggested some viable strategies needed to engender sustainable development in Nigeria. It is the belief of this research exercise that if these options and models are faithfully and judiciously pursued and imbibed, Nigeria will be well positioned in the global economy by the year 2030 . The study found and recommends that:

Political and policy instability from the results has a higher and strong negative significant effect on Nigerian economic growth and development. This includes lack of policy and project continuity, incomplete and lack of implementation of law and budget within the fiscal year and tribalism. Based on the above, the study recommends for co-federal system of government and constitutional reform in Nigeria, which will go a long way to calm- down the effect political and policy instability on Nigerian economic growth and development.

There is the need for Nigeria to revamp the agricultural sector; this sector was instrumental in the development of Japan. Agriculture used to be the mainstay of Nigeria economy but the discovery of crude oil in the Niger Delta succeeded in putting agriculture into state of oblivion. Human resources development is also a sine qua non to Nigeria national development; this was demonstrated in Japan and Korea.
Development depends very much on human knowledge and skills. This must be such that a high quality of education and training is achieved for a large majority at a reasonable price and the context and quality of such education and training should be relevant and adequate to the country's development needs.

(3) Importantly, citizenship should be promoted over indignity in order to achieve cooperation and participation of all communities in the development process. The constitution sets parameters for indigenes and non-indigenes. It equally gives legal bases to various discriminatory policies that actively promote national unity contrary to some sections that argue against discrimination. Leadership in Nigeria must sustain previous policies and behave in a way to inculcate the spirit of patriotism in the minds of the people, so that the masses will be ready to stand with the government in her development efforts.

(4) Finally, the need to reform of electoral process is imperative for socio-economic and political development. Electoral fraud is one of the banes of Nigerian development. Such fraudulent electoral processes lead to the emergence of terrible political elite that promotes political and policy instability. The role of leadership in development cannot be overemphasized, all efforts towards development must be coordinated and directed by the leaders and therefore, the leaders must be development conscious and have genuine interest for national development and the political will to propel such development. The leaders must also have the cooperation of the Nigerian citizenry, because it is the people that develop a nation.

\begin{tabular}{|c|c|c|c|c|}
\hline Date: $12 / 29 / 16$ & |0:51 & & & \\
\hline Sample (adjust & 722015 & & & \\
\hline Included obser & 44 after adjus & & & \\
\hline Trend assumpt & ear determinis & & & \\
\hline Series: GEX G & GDP BM2 & & & \\
\hline Lags interval (i & fferences): $1 \mathrm{t}$ & & & \\
\hline Hypothesized & & Trace & 0.05 & \\
\hline No. of CE(s) & Eigenvalue & Statistic & Critical Value & Prob.** \\
\hline None * & 0.999979 & 641.7295 & 69.81889 & 0.0001 \\
\hline
\end{tabular}




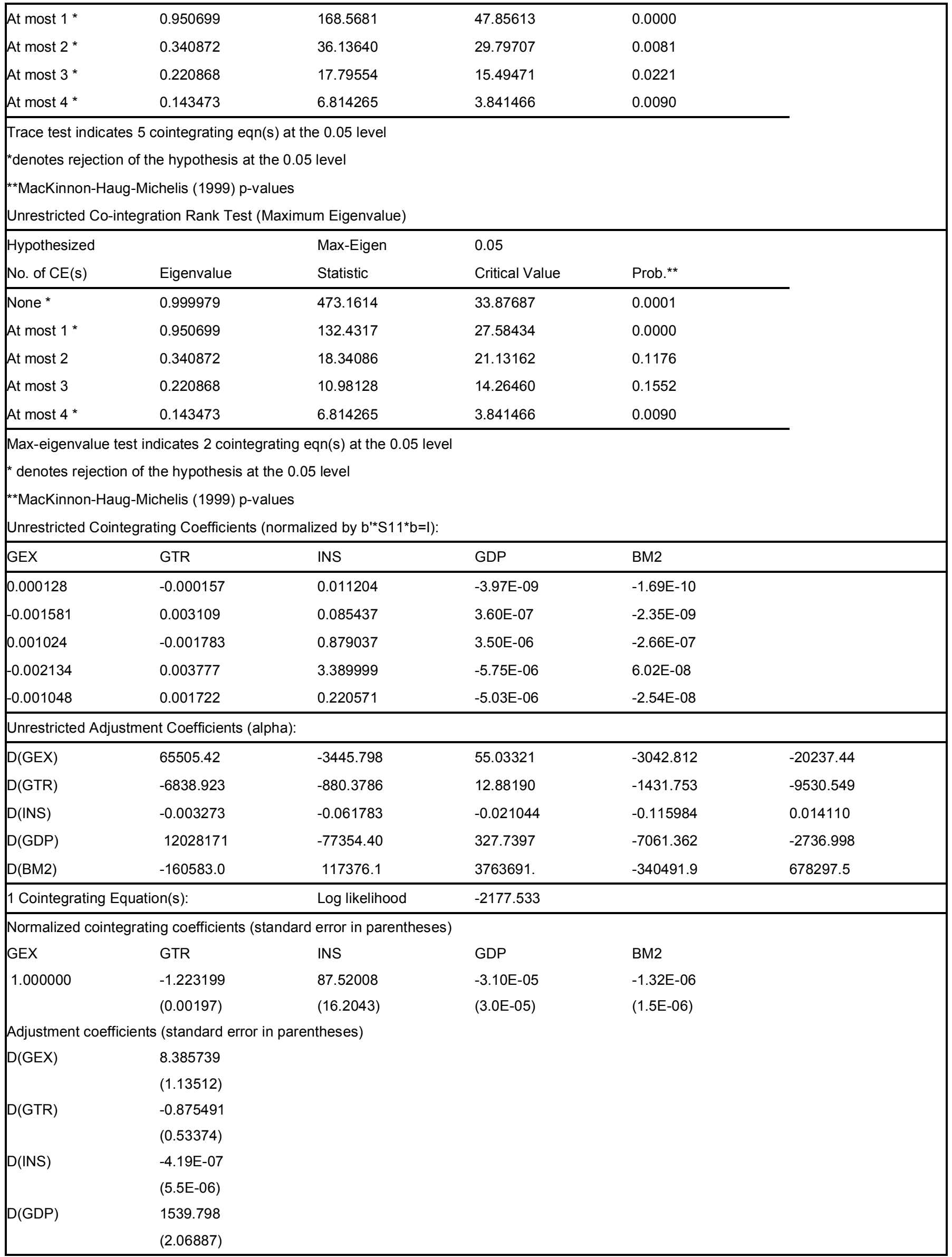




\begin{tabular}{|c|c|c|c|c|}
\hline $\mathrm{D}$ (BM2) & $\begin{array}{l}-20.55718 \\
(141.652)\end{array}$ & & & \\
\hline 2 Cointegr & on(s): & Log likelihood & -2111.317 & \\
\hline Normalize & ng coefficien & error in parenth & & \\
\hline GEX & GTR & INS & GDP & BM2 \\
\hline 1.000000 & 0.000000 & 320.3408 & 0.000292 & $-5.93 E-06$ \\
\hline & & (111.664) & (6.0E-05) & $(1.0 \mathrm{E}-05)$ \\
\hline 0.000000 & 1.000000 & 190.3375 & 0.000264 & $-3.77 \mathrm{E}-06$ \\
\hline & & (87.2887) & (4.7E-05) & $(7.8 \mathrm{E}-06)$ \\
\hline Adjustmer & $\mathrm{s}$ (standard $\mathrm{e}$ & theses) & & \\
\hline$D(G E X)$ & 13.83246 & -20.97105 & & \\
\hline & (14.0331) & (27.5477) & & \\
\hline $\mathrm{D}(\mathrm{GTR})$ & 0.516110 & -1.666361 & & \\
\hline & $(6.60802)$ & $(12.9719)$ & & \\
\hline$D(I N S)$ & 9.72E-05 & -0.000192 & & \\
\hline & (6.6E-05) & $(0.00013)$ & & \\
\hline $\mathrm{D}(\mathrm{GDP})$ & 1662.071 & -2123.989 & & \\
\hline & (15.8156) & (31.0468) & & \\
\hline $\mathrm{D}(\mathrm{BM} 2)$ & -206.0918 & 390.0896 & & \\
\hline & (1754.52) & (3444.22) & & \\
\hline 3 Cointegr & on(s): & Log likelihood & -2102.147 & \\
\hline Normalize & ng coefficien & error in parenth & & \\
\hline GEX & GTR & INS & GDP & BM2 \\
\hline 1.000000 & 0.000000 & 0.000000 & -0.001030 & 8.99E-05 \\
\hline & & & $(0.00013)$ & $(1.8 \mathrm{E}-05)$ \\
\hline 0.000000 & 1.000000 & 0.000000 & -0.000521 & $5.31 \mathrm{E}-05$ \\
\hline & & & (8.1E-05) & $(1.2 \mathrm{E}-05)$ \\
\hline 0.000000 & 0.000000 & 1.000000 & 4.13E-06 & $-2.99 \mathrm{E}-07$ \\
\hline & & & (3.7E-07) & $(5.2 \mathrm{E}-08)$ \\
\hline Adjustmer & $\mathrm{s}$ (standard e & ntheses) & & \\
\hline $\mathrm{D}(\mathrm{GEX})$ & 13.88883 & -21.06918 & 487.8987 & \\
\hline & (16.7053) & (31.7465) & (7815.78) & \\
\hline D(GTR) & 0.529304 & -1.689330 & -140.5162 & \\
\hline & $(7.86632)$ & (14.9490) & (3680.35) & \\
\hline $\mathrm{D}(\mathrm{INS})$ & 7.57E-05 & -0.000154 & -0.023813 & \\
\hline & $(7.8 \mathrm{E}-05)$ & $(0.00015)$ & $(0.03655)$ & \\
\hline$D(G D P)$ & 1662.407 & -2124.573 & 128442.4 & \\
\hline & (18.8269) & (35.7784) & (8808.40) & \\
\hline D(BM2) & 3648.688 & -6320.996 & 3316652. & \\
\hline & (1731.44) & $(3290.40)$ & (810076.) & \\
\hline 4 Cointegr & on(s): & Log likelihood & -2096.656 & \\
\hline Normalize & ng coefficien & error in parenth & & \\
\hline GEX & GTR & INS & GDP & BM2 \\
\hline 1.000000 & 0.000000 & 0.000000 & 0.000000 & 3.49E-05 \\
\hline
\end{tabular}




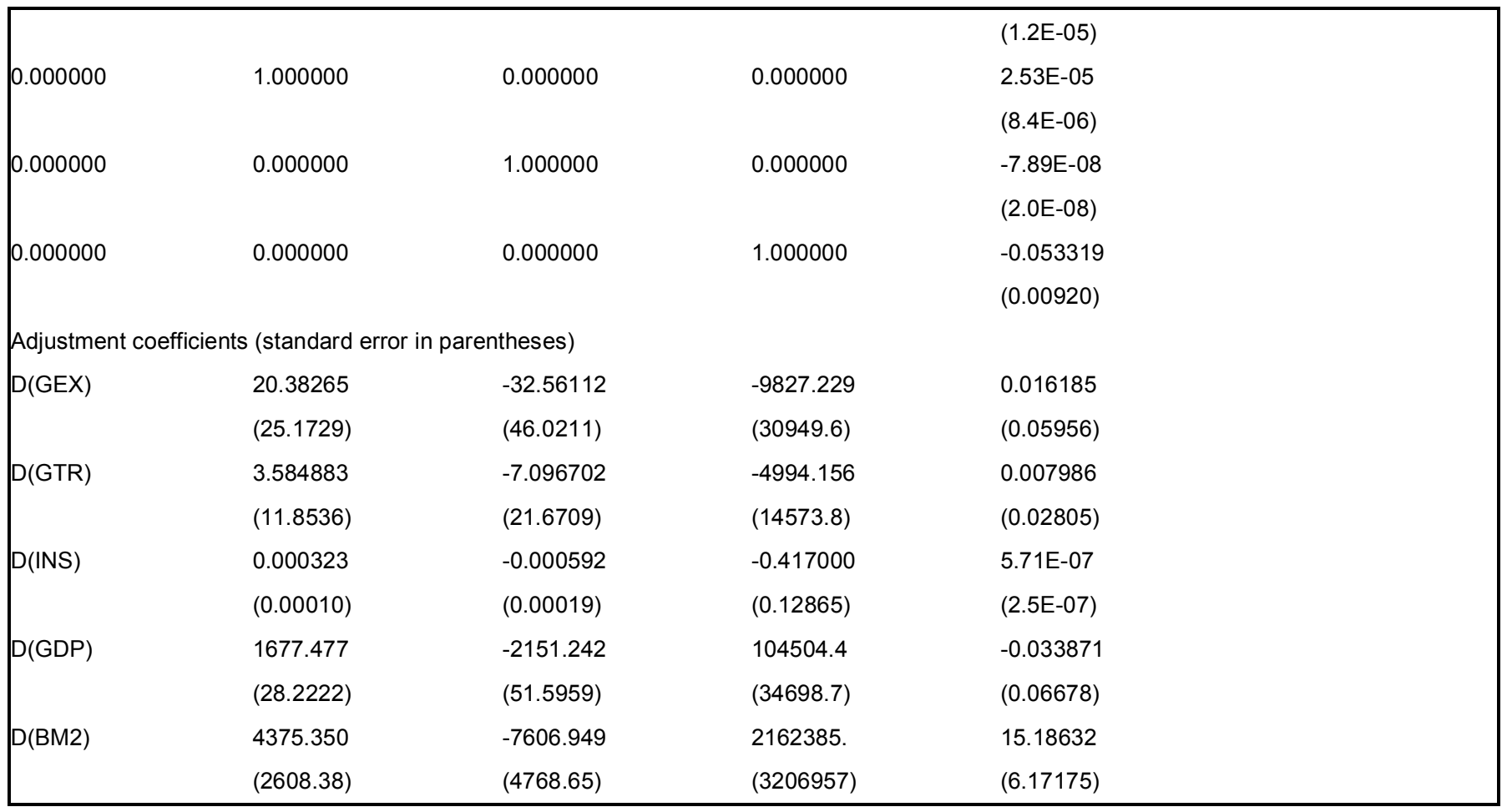

Null Hypothesis: Unit root (individual unit root process)

Series: GEX, GTR, INS, GDP, BM2

Date: 12/29/16 Time: 10:53

Sample: 19702015

Exogenous variables: Individual effects, individual linear trends

User-specified maximum lags

Automatic lag length selection based on AIC: 0 to 2

Total number of observations: 212

Cross-sections included: 5

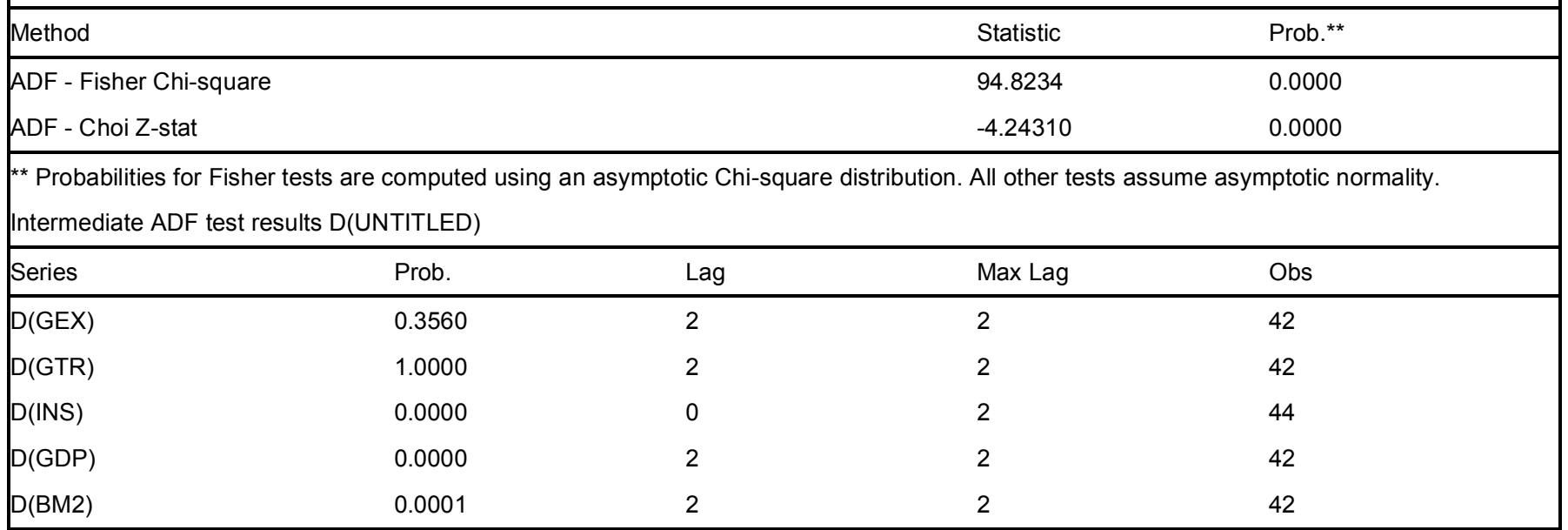


Null Hypothesis: Unit root (individual unit root process)

Series: GEX, GTR, INS, GDP, BM2

Date: 12/29/16 Time: 10:54

Sample: 19702015

Exogenous variables: Individual effects, individual linear trends

Newey-West automatic bandwidth selection and Bartlett kernel

Total (balanced) observations: 220

Cross-sections included: 5

\begin{tabular}{|c|c|c|c|}
\hline \multicolumn{2}{|l|}{ Method } & Statistic & Prob. ${ }^{\star *}$ \\
\hline \multicolumn{2}{|l|}{ PP - Choi Z-stat } & -12.9786 & 0.0000 \\
\hline \multicolumn{4}{|c|}{$\begin{array}{l}\text { ** Probabilities for Fisher tests are computed using an asymptotic Chi-square distribution. All other tests assume asymptotic normality. } \\
\text { Intermediate Phillips-Perron test results D(UNTITLED) }\end{array}$} \\
\hline $\mathrm{D}(\mathrm{GTR})$ & 0.9925 & 3.0 & 44 \\
\hline $\mathrm{D}(\mathrm{INS})$ & 0.0000 & 0.0 & 44 \\
\hline $\mathrm{D}(\mathrm{GDP})$ & 0.0000 & 4.0 & 44 \\
\hline D(BM2) & 0.0000 & 8.0 & 44 \\
\hline
\end{tabular}

Null Hypothesis: Unit root (individual unit root process)

Series: GEX, GTR, INS, GDP, BM2

Date: 12/29/16 Time: 10:54

Sample: 19702015

Exogenous variables: Individual effects, individual linear trends

Newey-West automatic bandwidth selection and Bartlett kernel

Total (balanced) observations: 215

Cross-sections included: 5

\begin{tabular}{|c|c|c|c|}
\hline \multicolumn{2}{|l|}{ Method } & Statistic & Prob. ${ }^{* *}$ \\
\hline \multicolumn{2}{|l|}{ PP - Choi Z-stat } & -26.0981 & 0.0000 \\
\hline \multicolumn{4}{|c|}{$\begin{array}{l}\text { ** Probabilities for Fisher tests are computed using an asymptotic Chi-square distribution. All other tests assume asymptotic normality } \\
\text { Intermediate Phillips-Perron test results } \mathrm{D}(\text { UNTITLED,2) }\end{array}$} \\
\hline $\mathrm{D}(\mathrm{GTR}, 2)$ & 0.0000 & 0.0 & 43 \\
\hline $\mathrm{D}(\mathrm{INS}, 2)$ & 0.0000 & 7.0 & 43 \\
\hline $\mathrm{D}(\mathrm{GDP}, 2)$ & 0.0000 & 42.0 & 43 \\
\hline $\mathrm{D}(\mathrm{BM} 2,2)$ & 0.0000 & 42.0 & 43 \\
\hline
\end{tabular}


Dependent Variable: GDP

Method: Least Squares

Date: 12/29/16 Time: 10:58

Sample: 19702015

Included observations: 46

\begin{tabular}{lllll}
\hline Variable & Coefficient & Std. Error & t-Statistic & Prob. \\
\hline C & 95555.96 & 1258734. & 0.075914 & 0.9399 \\
GEX & 117.1635 & 10.58856 & 11.06510 & 0.0000 \\
GTR & -34.50086 & 9.627263 & -3.583662 & 0.0009 \\
INS & -1651461. & 2264518. & -0.729277 & 0.4700 \\
BM2 & 0.096050 & 0.165985 & 0.578671 & 0.5660 \\
\hline R-squared & 0.842947 & Mean dependent var & & 4011779. \\
Adjusted R-squared & 0.827625 & S.D. dependent var & & 15456971 \\
S.E. of regression & 6417432. & Akaike info criterion & & 34.28926 \\
Sum squared resid & $1.69 \mathrm{E}+15$ & Schwarz criterion & & 34.48802 \\
Log likelihood & -783.6529 & Hannan-Quinn criter. & & 34.36371 \\
F-statistic & 55.01476 & Durbin-Watson stat & & 2.442513 \\
Prob(F-statistic) & 0.000000 & &
\end{tabular}

Dependent Variable: LOG(GDP)

Method: Least Squares

Date: 12/29/16 Time: 11:00

Sample: 19702015

Included observations: 46

\begin{tabular}{lllll}
\hline Variable & Coefficient & Std. Error & t-Statistic & Prob. \\
\hline C & -6.379421 & 2.272963 & -2.806655 & 0.0076 \\
LOG(GEX) & 0.845407 & 0.890113 & 0.949775 & 0.3478 \\
LOG(GTR) & 0.091205 & 0.919390 & 0.099201 & 0.9215 \\
INS & 0.085448 & 0.992111 & 0.086127 & 0.9318 \\
LOG(BM2) & 1.051756 & 0.167102 & 6.294095 & 0.0000 \\
\hline R-squared & 0.720647 & Mean dependent var & & 10.93545 \\
Adjusted R-squared & 0.693393 & S.D. dependent var & 4.017233 \\
S.E. of regression & 2.224426 & Akaike info criterion & & 4.539197 \\
Sum squared resid & 202.8709 & Schwarz criterion & & 4.737962 \\
Log likelihood & -99.40153 & Hannan-Quinn criter. & & 4.613656 \\
F-statistic & 26.44194 & Durbin-Watson stat & & 0.485335 \\
Prob(F-statistic) & 0.000000 & & \\
\hline
\end{tabular}


Dependent Variable: GDP

Method: Generalized Method of Moments

Date: 12/29/16 Time: 11:04

Sample (adjusted): 19712015

Included observations: 45 after adjustments

Linear estimation with 1 weight update

Estimation weighting matrix: HAC (Bartlett kernel, Newey-West fixed bandwidth $=4.0000$ )

Standard errors \& covariance computed using estimation weighting matrix

Instrument specification: LOG(GDP) C LOG(GEX) LOG(GTR) D(INS) LOG(BM2)

\begin{tabular}{|lllll|}
\hline Variable & Coefficient & Std. Error & t-Statistic & Prob. \\
\hline C & -706805.3 & 361750.3 & -1.953849 & 0.0577 \\
GEX & 115.7080 & 28.61057 & 4.044239 & 0.0002 \\
GTR & -39.37461 & 18.07285 & -2.178661 & 0.0353 \\
D(INS) & -22212.70 & 100109.7 & -0.221884 & 0.8255 \\
LOG(BM2) & 80648.86 & 26538.01 & 3.038994 & 0.0042 \\
\hline R-squared & 0.838465 & Mean dependent var & & 4100928. \\
Adjusted R-squared & 0.822312 & S.D. dependent var & 15619667 \\
S.E. of regression & 6584174. & Sum squared resid & & $1.73 E+15$ \\
Durbin-Watson stat & 2.380965 & J-statistic & 1.399763 \\
Instrument rank & 6 & Prob(J-statistic) & 0.236763 \\
\hline
\end{tabular}

\begin{tabular}{|c|c|c|c|c|}
\hline \multicolumn{5}{|c|}{$\begin{array}{l}\text { Dependent Variable: GDP } \\
\text { Method: Two-Stage Least Squares } \\
\text { Date: 12/29/16 Time: } 11: 36 \\
\text { Sample (adjusted): } 19712015 \\
\text { Included observations: } 45 \text { after adjustments } \\
\text { Instrument specification: LOG(GDP) C INS LOG(GEX) LOG(GTR) LOG(BM2) }\end{array}$} \\
\hline Variable & Coefficient & Std. Error & t-Statistic & Prob. \\
\hline C & 155020.0 & 1230549. & 0.125976 & 0.9004 \\
\hline $\mathrm{D}(\mathrm{INS})$ & -6294123 & 5086454. & -1.237428 & 0.2231 \\
\hline GEX & 101.1208 & 19.29872 & 5.239765 & 0.0000 \\
\hline GTR & -31.76129 & 19.37855 & -1.638993 & 0.1091 \\
\hline BM2 & -0.003832 & 0.256244 & -0.014953 & 0.9881 \\
\hline R-squared & 0.826064 & Mean dep & & 4100928. \\
\hline Adjusted R-squared & 0.808670 & S.D. depe & & 15619667 \\
\hline S.E. of regression & 6832244. & Sum squa & & $1.87 E+15$ \\
\hline F-statistic & 32.51859 & Durbin-W & & 2.363063 \\
\hline Prob(F-statistic) & 0.000000 & Second-S & & $4.66 \mathrm{E}+15$ \\
\hline $\mathrm{J}$-statistic & 1.611164 & Instrumen & & 6 \\
\hline Prob(J-statistic) & 0.204328 & & & \\
\hline
\end{tabular}




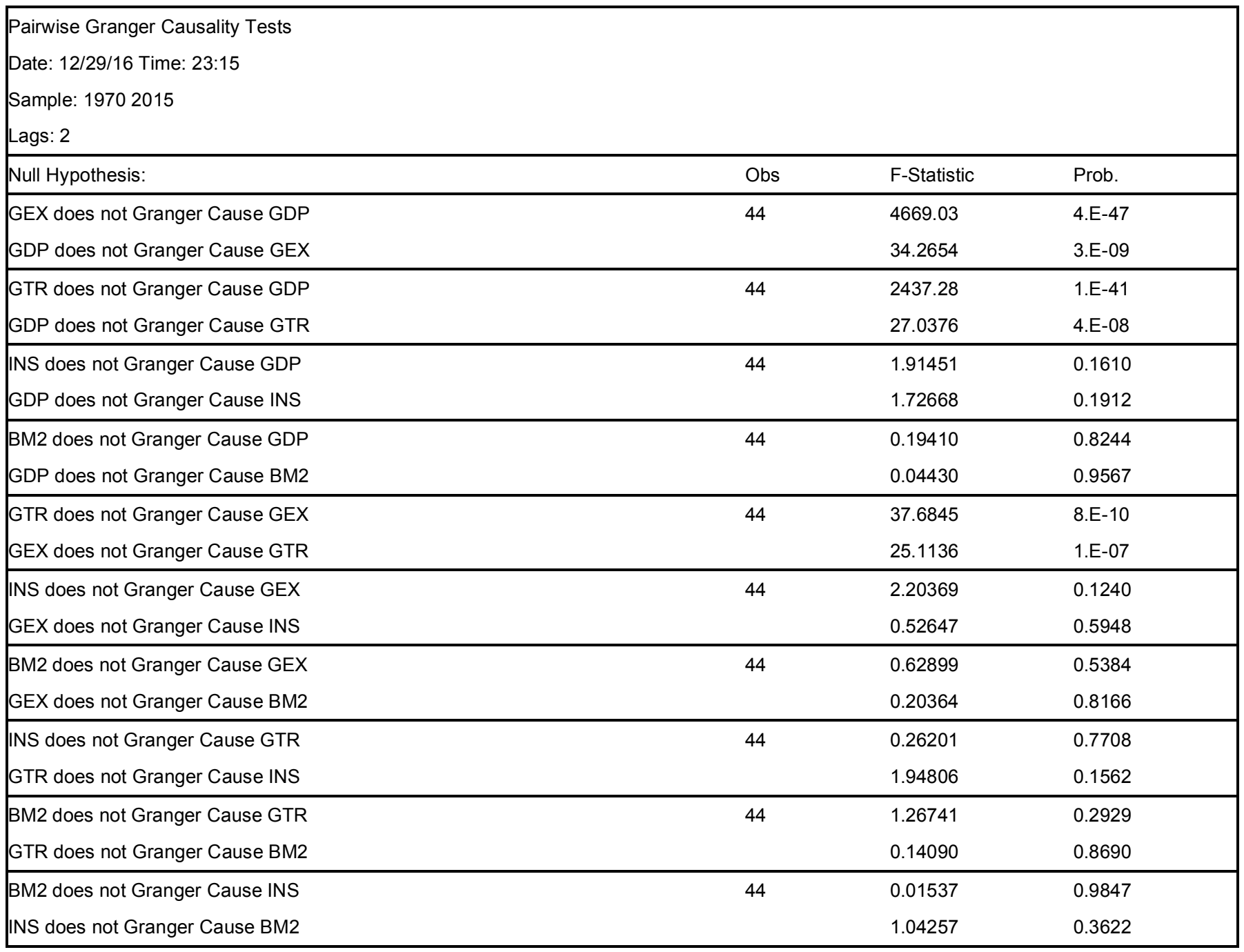

\section{REFERENCES}

Abdulahi, S.A. (2005), Capital market performance and economic development in Nigeria, An empirical analysis paper presented at the Department of Business Administration, Bayero University Kano.

Adelman, I. (1995), Social development in Korea, 1953-1993, Paper Presented in the International Conference on the Korea Economy 1945-1995, Korea Development Institute, Seoul, December, pp 9-10.

Adamu, J. A. \& Sanni, I. (2005), Stock market development and Nigerian economic growth. Journal of Economic and Allied Fields, 2(2):116-132

Adejumobi, S. (2004), "Democracy good governance and constitutionalism in Africa, in Sylvester Odion-Akhaine, Governance: Nigeria in the World, (Lagos: Centre for Constitutionalism and Development) pp: 11-2.

Adekanye, B. J. (1993), "Military occupation and social stratification", An Inaugural Lecture delivered at the University of Ibadan, on November 25.

Adeniyi, S. (2006), "Wolfowitz: Nigeria Has Lost $\$ 300$ billion to Corruption", This Day, Centre for Constitutionalism and Development 11 (4196) 17 p. 3.

Adeseyoju, A. (2006), "Gatekeepers as Money Launderers”, The Guardian, 08/09/06. pp. 24-26.
Adeyemo, W. (2006), "Striking the Right Chord". Tell Magazine, No. 8 February 20 24- 26

Afees, A. S. \& Kazeem, B. A. (2010), The Stock Market and Economic Growth in Nigeria: An Empirical Investigation, Journal of Economic Theory, (4): $65-70$.

Agarwal, S. (2001), Stock Market Development and Economic Growth: Preliminary Evidence from African Countries, W.B Document

Ake, C. (1981), A political economy of Africa (Essex: Longman)

Ake, C. (1995), "Socio-political approaches and policies for sustainable development in Africa", A paper delivered at the Annual Meeting/ Symposium of the African Development Banks, Abuja, May, 25, 1995.

Akinseye-George, Y. (2000), "Jurist Nigerian Correspondent" in <http: //jurist.lawpitt.edu/world/nigeria.cor.2.html>

Alesina A. \& Tabellini, G. (1990), "A positive theory of fiscal deficits and debt," Review of Economic Structures, July.

Alesina A. \& Tabellini, G. (1989), "External debt, capital flight and political risk," Journal of international Economics, November.

Alesina, A. \& Rodrik, D. (1991), "Distributive politics and economic growth," NBER Working Paper No. 3668.

Albert OI (2005), "Terror as a political weapon: reflections on the bomb explosions in Abacha's Nigeria" IFRA Ibadan, Special Research Issue, (1) 37- 56. 
Alatas V. (2006), "Gender and corruption: insight from an experimental analysis"<http://www.economics.unimelb.edu. au/lcameron/papers/gender/pdf>

Aremu, I. (2003), Development and political stability in Mike Kwanashie (ed) Politics and Political Power Relations in Nigeria, (Lagos: Dat and Partners Logistic Ltd) 248-262.

Ariyo, A. \& Adelegan, O. (2005), Assessing the impact of capital market reforms in Nigeria: An Incremental Approach. Paper Presented at 46th Annual Conference of the Nigeria Economic Society in Lagos, August

Ayeni, V. (1988), "Of Presidentialism and Third World Political Process: Introduction, in Victor Ayeni and Kayode Soremekun" Nigeria's Second Republic (Apapa: Daily Times Publications).

Ayittey, B. N. G. (2006), Nigeria's struggle with corruption (A testimony before the Committee on International Relations Subcommittee on Africa, Global Human Rights and International Operations House Committee on Africa, U.S. House of Representatives, Washington, D.C, Thursday, May 18.

Barro, R. (1989), "A Cross Country Study of Growth, Saving and Government," NBER WP No. 2855, February.

Barro, R. (1991), "Economic growth in a cross section of countries," Quarterly Journal of Economics, May

Bello-Imam IB (2004), Corruption and national development, in I.B. Bello-Imam \& Mike Obadan (eds.), Democratic governance and development management in Nigeria's fourth republic, 1999-2003,(Ibadan: Centre for Local Government and Rural Development Studies).

Chinwuba, O. \& Amos, O.A. (2011), "Stimulating economic development through the capital market: the Nigerian experience". JORIND 9(2) in www.transcampus.org

Cukierman, A., S. Edwards \& G. Tabellini (1992), "Seignorage and Political Instability," American Economic Review

Diamond, L. (1991), "Political corruption: Nigeria's perennial struggle" Journal of Democracy, 2 (4): 73-85. https://doi.org/10.1353/jod.1991.0056

Daniel, A. (2006). "Obasanjo unveils options to pay London Club debt", The Guardian, November 1.

Darah, G. G. (1995), "Dying for the Niger Delta". The Guardian, 19/11/1995, pp. B1-B2.

Dike, V. (nd), "Corruption in Nigeria: A new paradigm for effective control" http://www.africaneconomicanalysis.org/articles/gen/ corruptiondike

Ewah, S. O. E., Esang, A. E. \& Bassey J. U. (2009), Appraisal of capital market efficiency on economic growth in Nigeria, International Journal of Business and Management,4 (12): $219-225$ https://doi.org/10.5539/ijbm.v4n12p219

Epia, O. (2006), "Leaders Stashed Away \$500billion". ThisDay, Vol.11, (4196), October, 17.
Fagbadebo, O. (2000), "The Quest for a stable Nigerian federalism at the 1994/95 Constitutional Conference", A Research Thesis submitted to the Obafemi Awolowo University, Ile-Ife, for the award of Master of Science degree in Political Science

Gray, C. W., Kaufmann, D. (1998), "Corruption and development" in http://www.worldbank.com/fandd/english/0398/articles/02039 $8 / \mathrm{html}$.

Gboyega, A. (2003), "Democracy and development: The imperative of local governance", An Inaugural Lecture, University of Ibadan, pp 6-7.

Goodrich, S. (1992), "Political instability as a Determinant of U.S Foreign direct investments," Harvard University Senior.

Grossman, H. (1991), "A General equilibrium theory of insurrections, "American Economic Review, forthcoming.

Heckman, J. (1978), "Dummy endogenous variables in a simultaneous equation system," Econometrica. https://doi.org/10.2307/1909757

Londregan, J. \& Poole, K. (1990), "Poverty, the coup trap, and the seizure of executive power," World Politics, January

Londregan, J. \& Poole, K. (1991a), "The seizure of executive power and economic growth: Some Additional Evidence," May.

Mimiko, O. (1998), "The State and the growth/Development Agenda: Africa and East/Asia in Context in Kolawole D. (ed)" Issues in Nigerian Government and Politics, (Ibadan, Dekaal Publishers) 163-166

Mimiko, O. (1997), The Global Village: Selected Topics on International Economic Relations, (Akure: Olaniyan Publishing Company) 6-7.

Naomi, O. (1995), "Towards an Integrated View of Human Rights", Hunger Teach Net, 6(3): 6-7.

Newey, W. K. (1987), "Efficient estimation of limited dependent variable models with endogenous explanatory variables," Journal of Econometrics

Ogwumike, F. (1995), "The effects of macro level government policies on rural development and poverty alleviation in Nigeria", Ibadan Journal of Social Sciences, 1(1): 85-101

Osinubi, T. S.\& Amaghionyeodiwe, L.A. (2003). Stock market development and long-run growth in Nigeria .Journal of African Business, 4 (3), 103-129. https://doi.org/10.1300/J156v04n03_06

Obamiro, J. K. (2005). Nigerian economy: growth and the role of stock market. Journal of Economic and Financial Studies, 2(2).

Pedro S. Amaral \& Erwan Quintin (2004), The implications of capitalskill complementarily in economies with large informal sectors', Center for Latin America Working Papers, 0404 Federal Reserve Bank of Dallas.

Tabellini, G. \& Alesina, A. (1990), "Voting on the Budget Deficits," American Economic Review, March.

Terrones, M. (1989), Influence activities and economic growth, unpublished research paper

\section{DOl: https://doi.org/10.6000/1929-7092.2019.08.08}

(C) 2019 Nwadike et al.; Licensee Lifescience Global.

This is an open access article licensed under the terms of the Creative Commons Attribution Non-Commercial License (http://creativecommons.org/licenses/by-nc/3.0/) which permits unrestricted, non-commercial use, distribution and reproduction in any medium, provided the work is properly cited. 